\title{
Knowledge making practices as vehicles for teaching academic literacy
}

\section{Bente Kristiansen}

Aarhus University, Denmark

\section{Abstract}

Several studies have established a connection between how a discipline communicates in texts and how disciplinary knowledge is produced (e.g. Bazerman, 2000; Blåsjö, 2004; Carter, 2007). This article suggests that a didactic consequence of such a connection could be to use the rhetorical contexts and the knowledge-making practices as vehicles for teaching academic literacy. A conceptual framework for doing this in practice is presented, including teaching and learning activities.

Keywords: academic literacy, academic writing, knowledge-making practices, discourse communities, teaching academic writing.

\section{Introduction}

In this article I understand academic literacy as 'the ability to communicate competently in an academic discourse community' (Wingate, 2015, p. 6). From this presumption follows that teaching academic literacy can be seen as a matter of teaching students how to understand and master the rhetorical context for communicating in an academic discourse community. I further understand academic texts as 'social interaction with the purpose of presenting knowledge claims and persuading peers to assent these knowledge claims' (Hyland, 2004, p. 12). From this presumption follows that the way knowledge is produced and argued for (the knowledge making practices) is crucial for communication in academic discourse communities. This article is about how these two presumptions can contribute to a framework for teaching academic literacy in a disciplinary context. 


\section{Epistemologies and writing conventions}

Several studies have shown how writing conventions differ from one academic discipline to another (Bazerman 2000; Blåsjö 2004; Hyland 2004; Carter 2007; Nesi and Holmes 2010). Blåsjö (2004) has pointed out significant differences in student writing, professional discourses and educational settings between the Department of History and the Department of Economics at Stockholm University. Blåsjö concludes that the epistemology of Economics is defined as rationalistic, dominated by a 'linear logical reasoning with clearcut solutions', while the epistemology of History is critical-pluralistic, dominated by reasoning with a multitude of perspectives (Blåsjö, 2004, p. 2).

Such differences in epistemology and thinking can also be seen in specific linguistic features. Nesi and Holmes (2010) show how the identities of agents are commonly suppressed in Physics to emphasise 'that knowledge is derived from replicable laboratory activities, observations and measurements' (p. 67). In the field of History, on the other hand, identities of authorities and sources are important in establishing their validity and relevance, and therefore academic texts in History have explicit agents (Nesi and Holmes, 2010, p. 67).

It seems that academic texts entail - and can reveal - implicit ways of thinking in a discipline. Declarative knowledge, like methods (surveys, interviews, laboratory work, text analysis etc.), is usually described and thus made visible for discussion and critique. But some ways of disciplinary thinking are much more 'hidden', for instance whether agents should be visible or not, or whether the argumentation should be logical-rationalistic or provide many perspectives. These ways of thinking and working in a discipline are hidden in disciplinary literacy.

Therefore, the aim of teaching academic writing should not be to master writing conventions, but to understand the interdependence between knowledge-making, disciplinary thinking and textual features in an academic discipline. In the following, I will present some scholars who have developed tools and strategies that subject teachers can use when teaching disciplinary content, while also maintaining a strong focus on knowledge-making practices and how these relate to rhetorical practices (Carter 2007; Bizup 2008; Bean 2011). 


\section{Knowledge-making practice and text production}

Carter (2007) explains the lack of interest in literacy that many subject teachers have as a consequence of how knowledge is understood. If knowledge is understood as something more or less static and education is seen as the delivery of knowledge, then writing will be seen as separated from the discipline, as 'knowing what'. On the other hand, if knowledge is understood as active ways of knowing, then writing will be understood in connection to the way knowledge is produced, as 'knowing how'. Carter refers to learning theories in which we see the same distinction between conceptual (declarative) knowledge and procedural (process) knowledge.

One way of making this connection between disciplinary knowledge-making practices and the literacy practices visible - and relevant for disciplinary teachers - is to guide academic staff in identifying ways of 'doing' ('knowing how') in their disciplines. When Carter asked academic staff about learning outcomes in different disciplines, Zoology staff mentioned two key disciplinary ways of doing: being able to engage in scientific inquiry and being able to solve problems in Zoology (Carter, 2007, p. 390). The question about how to assess these kinds of learning outcomes got the answer: different kinds of texts, e.g. lab reports, scientific papers, posters, management plans, project proposals and environmental statements. These texts represent different ways of 'doing' in the discipline. Carter identified four different ways of 'doing' across faculties, named metadisciplines. Some disciplines (e.g. Business, Engineering, Economics) solve practical problems for clients, and they often write in genres like reports or management plans. Other disciplines (e.g. Physical and Social Sciences) focus on empirical enquiry, while others are interpretive/theoretical (mostly Humanities). The fourth metadiscipline is performative disciplines like Journalism and Rhetoric.

From this perspective, academic literacy is about understanding the purpose of the specific text, for instance presenting a solution to a problem or investigating a problem. And students need more than conceptual knowledge to write these genres, they need knowledge about how to 'do' the discipline. Misunderstandings of how to 'do' the discipline will result in texts that do not meet the writing conventions for the given genre in the given 
discipline. Therefore, the 'doing' of the discipline, as the core of the knowledge-making practices, is a relevant focus for both the subject teacher and the writing teacher.

Bean is another writing scholar who focuses on disciplinary knowledge-making and disciplinary writing. Bean has developed a concept of three one-hour workshops for academic staff. His aim is to show subject teachers that teaching writing is also a matter of teaching subject matter knowledge (Bean, 2011, p. 219).

Bean's argument starts with MacDonald's (1994) description of how an academic writer develops through four stages. The first stage is non-academic writing (primary school and high school), the second is generalised academic writing (freshman courses teaching 'academic writing'), the third is writing novice approximations of particular disciplinary ways of making knowledge (written discipline-specific assignments), and the last stage is expert insider prose (Bean, 2011, p. 217). Assignments can be used to develop 'expert' insider prose by improving the disciplinary ways of conducting inquiry and making arguments. Bean also presents Beaufort's model (Beaufort, 2007) of different knowledge domains: subject matter knowledge, genre knowledge, rhetorical knowledge and writing process knowledge. For Beaufort, these overlapping knowledge domains represent knowledge needed to participate in an academic discourse community.

According to Bean, these workshops, and especially the term 'expert insider prose', make disciplinary academic staff realise that they as subject specialists actually 'own' the teaching of disciplinary writing (Bean, 2011, p.219). Next, Bean opens a discussion about which discourse communities students in a specific discipline must be able to join (Bean, 2011, p. 221). As a frame for this discussion, Bean introduces Carter's (2007) concept of metadisciplines and metagenres, and asks what kind of writing their students should be able to do. In Bean's last workshop, the academic staff discuss how students understand 'research' and what they need to learn about research. Many students have a naïve understanding of research as similar to going to the library to borrow some books (Bean, 2011). Therefore, Bean introduces another way of talking about sources, namely a vocabulary developed by Bizup (2008) in which sources are labelled on the basis of the rhetorical function they have in the academic paper.

Bizup (2008) argues that labelling the sources primary, secondary and tertiary is not meaningful for students because these words do not refer to the rhetorical function of the sources. Bizup instead suggests that sources are labelled according to their different 
rhetorical purposes. If students are to adopt a rhetorical perspective toward researchbased writing, then it is important to use language that focuses the attention on what writers might do with the sources (Bizup, 2008, p. 75).

Bizup distinguishes between four rhetorical purposes for the use of sources. He uses the acronym BEAM for these:

- Some sources provide the Background, like factual knowledge or knowledge that the writer considers authoritative and that the reader is expected to consider as authoritative. The writer relies on background sources.

- Exhibit sources are 'materials a writer offers for explication, analysis, or interpretation' (Bizup, 2008, p. 75), for instance examples. Bizup emphasises that he does not mean evidence. Evidence is data supporting a claim, whereas exhibits can lend support to claims, and they can provide occasions for claims. The writer interprets or analyses exhibits.

- Argument sources are the sources that the writer engages with, builds upon or maybe argues against.

- Method sources are materials that provide the key concepts, a model or a specific perspective. The writer follows method sources.

What Carter (2007), Bizup (2008) and Bean (2011) have in common is their focus on the rhetorical context and how this is interconnected with knowledge-making practices. They build a bridge between disciplinary knowledge production and disciplinary text production. This bridge is where subject specialists and writing specialists could meet and cooperate around academic literacy. Writing specialists primarily contribute with what kind of questions and activities are relevant for mastering the rhetorical situation and understanding the connection to knowledge-making practices, while subject specialists primarily contribute with the specific disciplinary ways of producing knowledge and texts. Therefore, it is relevant to look at characteristics of the rhetorical context in academic discourse communities.

\section{The rhetorical context}


Beaufort (2007) has developed a simple model of five knowledge domains that an academic writer draws on. The model serves as a 'mental schema for learning writing skills in new genres in new discourse communities' (Beaufort, 2007, p.17). Thus the model offers an overview of important issues and I will use the model as a starting point for elaborating a framework for teaching academic writing.

Beaufort's model (2007) derives from a study of how students develop their writing throughout their academic education, including their shifting between disciplines. As a writing teacher in American freshman courses, Beaufort's focus is on how to teach transferable writing skills. Beaufort believes that by teaching the students broad concepts like discourse communities, rhetorical tools, genres etc., students will be able to understand and analyse new writing situations and recognise the specific demands of genres in new contexts (2007, p. 149).

The domains overlap, and together they represent the fifth knowledge domain, the discourse community. By this notion, Beaufort refers to the academic community in which knowledge is discussed: academic journals, conferences etc. A discourse community shares goals and values and establishes norms for genres (Beaufort, 2007, pp. 18-19).

Figure 1. Knowledge domains in academia (Beaufort, 2007, p. 19).

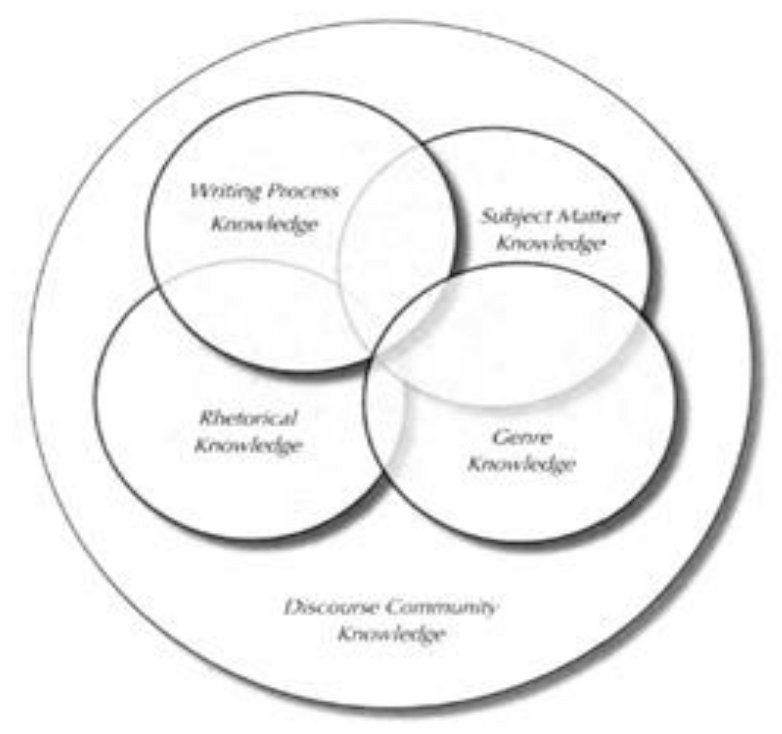

Rhetorical knowledge refers to ways of addressing a specific rhetorical situation, including understanding the purpose of the text (Beaufort, 2007). Subject matter knowledge is knowledge commonly acknowledged in a field. This includes factual knowledge, important theoretical disagreements, benchmark persons, methodological questions, specific 
terminology, the most important assumptions and arguments within the discipline, and acknowledged ways of using sources, producing empirical data and making an argument (Beaufort, 2007, p.19). Thus Beaufort is referring to both conceptual and procedural knowledge. Or, in Carter's terminology: both knowledge and knowing (Carter, 2007). According to Beaufort, genre knowledge refers to knowledge about the boundaries and features of genres defined and stabilised by the discourse community (2007, p.20). Based on Carter's (2007) understanding of genre as a way of doing a discipline, I will interpret this domain as knowledge-making practises. In most academic genres, two elements are crucial in the knowledge-making practice: the argumentation and the use of sources. Writing process knowledge refers to the ability to handle the writing process and the various phases and obstacles throughout the process.

In the following I will use this model of knowledge domains as an overall frame for teaching academic literacy. I argue that many common challenges for students can be understood in relation to these knowledge domains. Based primarily on Carter (2007), Bizup (2008) and Bean (2011), I will suggest teaching and learning activities in each knowledge domain that address these challenges by focusing on the connection between knowledge-making practises and texts. This is of course not a comprehensive examination of literacy problems in academia. It is a framework, offering a rhetorical perspective on academic literacy and putting the teaching of literacy in a disciplinary context.

\section{Rhetorical knowledge}

The purpose of academic texts is to argue for new knowledge, and to present new knowledge in a way that makes it possible for peers to discuss the production of this new knowledge (Jensen, 2004; Ask, 2007; Carter 2007). To many students, this is not obvious. Text genres in schools are in general reproductive writings or personal creative writings, or they are answers to specific questions (Krogh, 2010).

This also relates to the perception of knowledge. Many students enter university with a reproductive conception of learning (Clughen and Hardy, 2012). Studies (e.g. Nieminen et al., 2004) indicate that many students go through a development process during their studies, from having a dualistic understanding of knowledge to having a relativistic understanding. The understanding of knowledge as 'a set of clear, absolute, and unchangeable facts' (Nieminen et al., 2004, p. 390) is often related to an understanding of 
learning as the acquisition of knowledge from an outside source and is primarily aimed at reproducing knowledge. With this as the unconscious perception of knowledge, it is difficult to write in argumentative genres and position oneself as a participant in knowledge-making practices and engage in disciplinary dialogues. When this misconception of the purpose of academic writing is not addressed, it will take even longer for the individual student to go from a dualistic to a relativistic understanding of knowledge.

Another problem is the use of sources. In academic texts, the writer must engage in a dialogue with the discourse community. This dialogue will be based on references to what other members of the discourse community have written (Bazerman, 2000; Ask, 2007). The academic writer is expected to refer to important insights from within the field. This professional dialogue causes problems for students (Ask, 2007; Clughen and Hardy, 2012). Students have a tendency not to state the references, and they have a tendency not to indicate when they quote (Lunsford and Lunsford, 2008).

This is not only a matter of learning to use different reference systems. It is also basically a matter of developing an identity as a participant in an academic discussion. Developing an academic voice is challenging. Besides the basic perception of knowledge, it is also a question of developing an academic voice (Ask, 2007) and an identity as a legitimate participant in the discourse community.

One way of supporting this identity can be to provide the students with metaphors for their own role in the discourse community. The metaphors should visualise the student as an active subject producing a text. The idea is to emphasise how the student can act as a member of the discourse community. One metaphor could be comparing the literature review with a dinner table: imagine the student being the host deciding which scholars are invited, who will be seated at the most prominent seats, and who will have the most time to talk (Kamler and Thomson, 2006). Another possibility is to lend the students some phrases, known as 'syntactic borrowing' (Kamler and Thomson, 2006, p. 57): 'This study builds on and contributes to work in ...'; 'This study analyses ...'; 'I address this issue by demonstrating ...'. The purpose of syntactic borrowing is to eliminate the content to make the rhetorical moves visible and explicit.

\section{Subject matter knowledge}


An important activity for understanding subject matter knowledge is reading. However, reading an academic text also requires discipline-specific literacy (Shanahan and Shanahan, 2012). To read and fully understand an academic text, you must know what the crucial parts of information are and where to look for them. In Mathematics, the purpose of reading is to determine whether a proof is true or not. When mathematicians read, they pay attention to every single word, e.g. singular or plural, definite or indefinite singularity. Historians, on the other hand, are concerned about the sources. Even before reading, they pay attention to who the author is and what kind of bias the author might have (Shanahan and Shanahan, 2012, p. 49).

Therefore, many students need to develop discipline-specific reading strategies. Not just techniques such as skim-reading, but also strategies for finding the relevant information, doing critical reflections, comparing theories and arguments etc. Academic staff can support this process by asking questions focusing on the relevant topics in specific disciplines. Questions guiding the reading will support a deep learning strategy as the students will be searching for information and trying to make connections instead of simply memorising.

Students' reading can also be supported by showing their own reading strategy. Talk about: What exactly do you pay attention to when reading an academic text? What is important? What is irrelevant? What do you look for first? How do you decide on what to read and what not to read? (Bean, 2001, p. 138).

Another important element in subject matter knowledge is discipline-specific terminology. Some expressions or concepts might have an everyday meaning as well as a very specific meaning in the academic disciplinary context (Ulriksen et al., 2009). One example is the word 'discussion'. In an everyday context, a 'discussion' can reflect different opinions on an issue, but in most academic disciplines a discussion follows some rather strict rules. These rules are related to how knowledge is validated, and therefore a discussion in Literature will unfold quite differently compared to a discussion in Economics.

One way of handling this challenge could be many small writings in which the students can work with the meaning of different words. Ask the students to: Name the two most important differences between ... and ...; Give an example of ...; Explain this concept to your grandma ... Where have you met the concept ... before? Questions that help relate 
new concepts and terminology to previous knowledge and experiences will be especially helpful. Some of these could be of a more reflective character: What surprised you in the text? What was new to you? What is difficult to understand?

\section{Genre knowledge}

One way of describing argumentation in academic texts is that the author makes a knowledge claim and argues for this claim in a way that can be acknowledged in the discourse community (Hegelund and Kock, 2003; Jensen 2004; Ask 2007). Therefore, an important part of genre knowledge in academia is based on the understanding of how to argue for and/or to document knowledge production.

The way of arguing varies, but some simple tools can be used for investigating and explicating how the argumentation works in a discipline and how sources can be used. Hegelund and Kock (2003) argue that what is central in relation to the problems students have with writing academic papers is that they do not understand the overall purpose of the texts or how the different components contribute to the overall purpose (Hegelund and Kock, 2003, p. 75). They suggest using Toulmin's argument model (Toulmin, 1958) as an analytical tool and as a tool for producing and critiquing an academic argumentation. The three basic elements in the model are claim, data and warrant (Hegelund and Kock, 2003). The claim (or hypothesis) must be supported by data. Data can be own empirical studies, studies conducted by others or authoritative statements within the field. If we as readers are to acknowledge the data as valid support for the claim, the data must have a warrant, something that is agreed upon in the discourse community, usually methods, and sometimes theories. For instance, if the data is a focus group interview, we only acknowledge it as data when it has been carried out and documented in a way that is normally accepted within the field.

Academic discourse communities have critical discussions, and Toulmin's model has three more elements addressing the investigation of such discussions. Methods can be criticised, so the element of refutation is important. But we also have an element of backing to cover that the method - in spite of these acknowledged weaknesses - is still valid. The sixth element is the strength marker in the conclusion, indicating how sound the conclusion based on all this is. 
The strength of this argument model is that it helps students understand that the purpose of the text is argumentation, not regurgitation. It also provides an overview of how elements are connected. There is no focus on surface genre features, but on highlighting the meaning-making elements. The model also makes it possible for the subject teacher to show how different kinds of data and different kinds of warrants can form a valid argument in the discipline. If students are working cross- or interdisciplinarily, they might use the model for analysing different ways of arguing in the different disciplines. And, the model also shows how the warrant, the reason we acknowledge data as support for a claim, is not a granted everlasting truth. It is what members of a certain discourse community agree on at a certain time.

Another significant element in academic genres is the use of sources. Here Bizup's (2008) suggestion of naming the sources based on their rhetorical purposes can help students gain a better understanding of the different purposes that sources can have in their text. There are basically two ways of working with BEAM: either identifying the sources in a written text according to BEAM, or using BEAM in the writing process, that is asking about the rhetorical function of each source, for instance by asking students to write an annotated bibliography, describing which sources serve which rhetorical purpose.

\section{Writing process knowledge}

From a teaching and learning perspective, writing process knowledge is very important, because writing is also a learning process (Emig, 1977). Writing is also valuable for learning the terminology, and for practicing the way of thinking and arguing in the discipline.

A very important insight into the writing process is the distinction between writing to explore and writing to present (Dysthe et al., 2001). Writing to explore is writing notes, paraphrases, crazy ideas and questions - the writing one does in order to think, to investigate, to understand, to go deeper into the issue. Writing to present is writing for an audience, the writing that explains everything in a clear and logical way to the reader. Some instances of writer's block might come from a misunderstanding about these ways of writing. If students expect their writing to be well written and nicely presented from the start instead of using the writing to explore the issue, they might lose confidence in their own writing. As one student expresses: 
My problem is that I never realised that it is normal to write in a bad manner in the beginning but it gets better when you keep on working. I was good in school. I have pretty much done only what I was good at. I have been good at many things. It is really hard to realise this late that practice makes perfect, and that you can ask for help. To me this feels like failure (Kristiansen, 2017, p. 139).

It can be liberating in relation to the students' writing process to show them that writing is a way of learning, a way of getting to know the subject, and that it is important to write to explore before you can write to present. To further legitimise explorative writing, academic staff can provide many opportunities for short writing activities. The Thinking-Writing project at the Queen Mary University of London (www.thinkingwriting.qmul.ac.uk) shows many examples from different disciplines. Also speedwriting, reflective writing and social writing (Murray, 2009) can support writing processes.

\section{Participating in a discourse community}

Together, these knowledge domains form the knowledge and competences needed to participate in the discourse community. In higher education, there are several possibilities for giving students access to 'real' discourse communities: Seminars with peer feedback and participation in research activities and maybe conferences. Class discussions can be conducted in the same way as a scholarly discussion at a conference. The written participation takes the form of a Bachelor's project, a Master's thesis or articles for scholarly journals or student journals.

What seems to cause problems for students is when teachers expect them to be able to jump right into the discourse community without any kind of teaching in the other knowledge domains. Within each domain, students face challenges: new ways of thinking, reading, writing and talking. The table below shows some didactic consequences of the argument I have made in this article: that mastering academic writing and writing conventions is about understanding the rhetorical situation and having knowledge in all five knowledge domains. 
Many of the challenges that students face when writing academic texts relate to these domains. This understanding of students' challenges as related to the rhetorical situation not only allows for placing the subject specialist in the forefront, but it also provides some guidance regarding what kind of questions need to be addressed in teaching. The first column in the table refers to the knowledge domains. The second column refers to some common challenges that students face in this domain. The third column are suggestions for pedagogical strategies and learning activities, representing ways of making hidden conventions explicit. These suggestions are generic. The specific learning activities should have a disciplinary content and design. This is where the writing specialists and subject specialist together might form a fourth column with discipline specific variations.

Table 1. A framework for teaching academic literacies.

\begin{tabular}{|c|c|c|}
\hline $\begin{array}{l}\text { Knowledge } \\
\text { domain }\end{array}$ & $\begin{array}{l}\text { Common } \\
\text { challenges for } \\
\text { students }\end{array}$ & $\begin{array}{l}\text { Learning activities that address these } \\
\text { challenges by focusing on the relation between } \\
\text { knowledge production and textual features }\end{array}$ \\
\hline \multirow[t]{3}{*}{$\begin{array}{l}\text { Subject } \\
\text { matter } \\
\text { knowledge }\end{array}$} & $\begin{array}{l}\text { Develop } \\
\text { relevant } \\
\text { discipline- } \\
\text { specific reading } \\
\text { strategies }\end{array}$ & $\begin{array}{l}\text { - Give introduction to the text: Why read it? What } \\
\text { to look for? Provide questions to answer when } \\
\text { reading } \\
\text { - Show how you yourself read disciplinary texts } \\
\text { (e.g. Christensen, 2007) }\end{array}$ \\
\hline & $\begin{array}{l}\text { Understand } \\
\text { and master } \\
\text { concepts and } \\
\text { terminology in } \\
\text { the } \\
\text { discipline(s). }\end{array}$ & $\begin{array}{l}\text { - Give many opportunities for using new } \\
\text { terminology } \\
\text { - Acknowledge that imitation is part of the learning } \\
\text { process - give opportunities for } \\
\text { 'experimenting/playing with' the terminology } \\
\text { within the field }\end{array}$ \\
\hline & $\begin{array}{l}\text { Develop a deep } \\
\text { understanding } \\
\text { of concepts }\end{array}$ & $\begin{array}{l}\text { Provide opportunities for making connections } \\
\text { between abstract scientific knowledge and } \\
\text { concrete everyday experiences: examples, } \\
\text { analogies, metaphors etc. } \\
\text { - Use reflective writings or 'summing-up' writings }\end{array}$ \\
\hline \multirow{3}{*}{$\begin{array}{l}\text { Genre } \\
\text { knowledge }\end{array}$} & & \\
\hline & $\begin{array}{l}\text { Develop a } \\
\text { discipline- } \\
\text { specific } \\
\text { argumentation }\end{array}$ & $\begin{array}{l}\text { - Show what is valid argumentation in the } \\
\text { discipline by using an argument model - as a } \\
\text { tool for developing own argumentation or as a } \\
\text { tool for analysing others' argumentation (e.g. } \\
\text { Hegelund and Kock, 2003) }\end{array}$ \\
\hline & $\begin{array}{l}\text { Understand the } \\
\text { rhetorical } \\
\text { purposes of } \\
\text { sources in an }\end{array}$ & $\begin{array}{l}\text { - Focus on how different sources have different } \\
\text { rhetorical purposes in relation to the } \\
\text { argumentation (BEAM: Background, Exhibit, } \\
\text { Argument, Method (Bizup, 2008) }\end{array}$ \\
\hline
\end{tabular}




\begin{tabular}{|c|c|c|}
\hline & $\begin{array}{l}\text { academic } \\
\text { argumentation }\end{array}$ & $\begin{array}{l}\text { - Make literature search a part of teaching } \\
\text { - Ask students for an annotated bibliography }\end{array}$ \\
\hline & $\begin{array}{l}\text { Identify ways of } \\
\text { thinking and } \\
\text { working that } \\
\text { are significant } \\
\text { for the } \\
\text { knowledge } \\
\text { production in } \\
\text { the discipline }\end{array}$ & $\begin{array}{l}\text { - Analyse different genres used in the discipline: } \\
\text { what is the overall purpose of the text e.g. } \\
\text { problem solving, empirical investigation, } \\
\text { interpretation or performance? (Bean 2001; } \\
\text { Carter 2007; Bean, 2011) }\end{array}$ \\
\hline \multirow{4}{*}{$\begin{array}{l}\text { Rhetorical } \\
\text { knowledge }\end{array}$} & & \\
\hline & $\begin{array}{l}\text { Understand } \\
\text { what the reader } \\
\text { expects }\end{array}$ & $\begin{array}{l}\text { - Make your own reader expectations explicit } \\
\text { - Give feedback (or facilitate peer feedback) with a } \\
\text { focus on how the text meets criteria in relation to } \\
\text { methods, analysis, argumentation, the use of } \\
\text { references/sources etc. } \\
\text { - Invite people from relevant target groups to give } \\
\text { feedback on relevant texts }\end{array}$ \\
\hline & $\begin{array}{l}\text { Find own } \\
\text { academic voice } \\
\text { and identity in } \\
\text { the discourse } \\
\text { community } \\
\text { (Kammler and } \\
\text { Thomson, } \\
\text { 2006) }\end{array}$ & $\begin{array}{l}\text { - Use metaphors to support an identity as an } \\
\text { active participant in the discourse community } \\
\text { - Provide many opportunities for practicing a } \\
\text { discipline-specific discourse: oral, written, in } \\
\text { seminars, in groups }\end{array}$ \\
\hline & $\begin{array}{l}\text { Master different } \\
\text { rhetorical tools }\end{array}$ & $\begin{array}{l}\text { Analyse different kinds of discipline-specific text: } \\
\text { Structures, ways of addressing the reader, ways } \\
\text { of arguing, typical expressions etc. }\end{array}$ \\
\hline \multirow{3}{*}{$\begin{array}{l}\text { Writing } \\
\text { process } \\
\text { knowledge }\end{array}$} & & \\
\hline & $\begin{array}{l}\text { Master both } \\
\text { 'writing to think' } \\
\text { and 'writing to } \\
\text { present' } \\
\text { (Dysthe et al., } \\
2001 \text { ) }\end{array}$ & $\begin{array}{l}\text { - Make use of short writing-to-think tasks: } \\
\text { reflective writing, learning logs etc. } \\
\text { - Support writing to present: Show, analyse and } \\
\text { discuss successful examples of texts in relevant } \\
\text { genres }\end{array}$ \\
\hline & $\begin{array}{l}\text { Share writing } \\
\text { processes }\end{array}$ & $\begin{array}{l}\text { - Support the students in sharing the writing } \\
\text { process with peers, e.g. writing retreats, half- } \\
\text { hour writing meetings (Murray, 2009; 2012) }\end{array}$ \\
\hline \multirow{2}{*}{$\begin{array}{l}\text { Discourse } \\
\text { community } \\
\text { knowledge }\end{array}$} & & \\
\hline & $\begin{array}{l}\text { Participate in a } \\
\text { discourse } \\
\text { community }\end{array}$ & $\begin{array}{l}\text { - Arrange seminars during the semester, give } \\
\text { students opportunities for presenting, } \\
\text { commenting and revising } \\
\text { - Involve students in research activities }\end{array}$ \\
\hline
\end{tabular}


- Have students participate in research seminars, conferences etc.

\section{Conclusion}

In this article I have suggested a conceptual framework for teaching academic literacy. This framework is based on two presumptions: One presumption is that 'academic literacy is the ability to communicate competently in an academic discourse community' (Wingate, 2015 , p. 6). To understand what this means, or what it takes to communicate competently in this context, I used Beaufort's model of knowledge domains. This model provides an overview of the kind of knowledge needed for communicating competently.

The other presumption is that academic texts are 'social interaction with the purpose of presenting knowledge claims and persuading peers to assent these knowledge claims' (Hyland, 2004, p. 12). This presumption along with many studies showing how disciplines produce knowledge in different ways and accordingly express their knowledge production in different ways, is the argument for including the relation between the knowledge-making practices and the rhetorical practices in the teaching of academic literacy.

I suggest Beaufort's model of knowledge domains as an overview of important issues related to communicating in a discourse community. Many of the challenges that students face in relation to disciplinary writing and learning can be related to these knowledge domains. If we understand the challenges not as linguistic challenges but as challenges in relation to communicating disciplinary knowledge, we must address these challenges with learning activities that address both the communicative aspect and the disciplinary content. This is what the learning activities suggested in this article are aiming to do. They all have the same purpose of making the connection between knowledge-making practices and text production explicit. This is important because any activity that can make the production of knowledge in a discipline or field a little more explicit will be a step forward towards a critical perspective on how knowledge is produced in a discipline, as well as a step forward towards demystifying academic writing. 


\section{References}

Ask, S. (2007) Vägar till ett akademiskt skriftspråk. Doctoral thesis. Växjö: Växjö University Press. Available at: swepub:oai:DiVA.org:vxu-1276 (Accessed: 3 April 2019)

Bazerman, C. (2000) 'Shaping written knowledge: the genre and activity of the experimental article in science'. WAC Clearinghouse Landmark Publications in Writing Studies. Available at: http://wac.colostate.edu/books/bazerman shaping/. (Accessed: 29 May 2019).

Bean, J. (2001) Engaging ideas. Jossey-Bass: San Fransisco.

Bean, J. (2011) 'Backward design: towards an effective model of staff development in writing in the disciplines', in Deane, M. and O'Neill, P. (eds). Writing in the disciplines. Universities into the 21st century. London: Palgrave Macmillan.

Beaufort, A. (2007) College writing and beyond: a new framework for university writing instruction. Utah, CO: Utah State University Press.

Bizup, J. (2008) 'BEAM: a rhetorical vocabulary for teaching research-based writing', Rhetoric Review, 27(1), pp. 72-86.

Blåsjö, M. (2004) 'Studenters skrivande i två kunskapsbyggande miljöer', Acta Universitatis Stockholmiensis. Stockholm Studies in Scandinavian Philology. New Series. 37. Stockholm: Almqvist \& Wiksell International.

Carter, M. (2007) 'Ways of knowing, doing, and writing in the disciplines'. College Composition and Communication, 58 (3), pp. 385-418. Available at: http://www.jstor.org/stable/20456952. (Accessed: 29 May 2019).

Christensen, L. M. (2007) 'Show me, don't tell me! Teaching case analysis by “Thinking aloud'. Perspectives: Teaching Legal Research and Writing, 15(2) pp. 142-145. 
Clughen, L. and Hardy, C. (2012) 'Student and staff expectations and experiences'. In: Clughen, L. and Hardy, C. (2012) Writing in the disciplines. Building supportive cultures for student writing in UK higher education. Bingley: Emerald.

Dysthe, O.; Hertzberg, F. and Hoel, T. L. (2001) Skrive for at lære - faglig skrivning i de videregående uddannelser, Århus: KLIM.

Emig, J. (1977) 'Writing as a mode of learning'. College Composition and Communication, 28(2), pp. 122-128.

Hegelund, S. and Kock, C. (2003) 'A good paper makes a case: teaching academic writing the macro-Toulmin way', in Bjørk, L., Bräuer, G., Rienecker, L., and Stray Jörgensen, P. (eds.) Teaching academic writing in European higher education, Amsterdam: Kluwer Academic Publishers,.

Hyland, K. (2004) Disciplinary discourses: social interactions in academic writing. Ann Arbor, MI: University of Michigan Press

Jensen, L. B. (2004) Fra patos til logos - videnskabsretorik for begyndere. Frederiksberg, Roskilde Universitetsforlag.

Kamler, B. and Thomson, P. (2006) Helping doctoral students write: pedagogies for supervision. New York: Routledge.

Kristiansen, B. (2017) Om at skrive på universitetet. Odense: University Press of Southern Denmark.

Krogh, E. ed. (2010) Videnskabsretorik og skrivedidaktik. Rapport om et forsknings- og udviklingsprojekt med deltagelse af Avedøre Gymnasium og HF'. Kongsholm Gymnasium og HF samt Syddansk Universitet.

Lunsford, A.A; Lunsford, K. J. (2008): “Mistakes are a fact of life': a national comparative study'. College Composition and Communication, 59(4) pp. 781-806 [Online]. Available at: http://www.jstor.org/stable/20457033. (Accessed: 29 May 2019). 
Murray, R. (2009) Writing for academic journals. Maidenhead: Open University Press

Murray, R. (2012) 'Social writing', in Clughen, L. and Hardy, C. Writing in the disciplines. Building supportive cultures for student writing in UK higher education. Bingley: Emerald.

Nesi, H. and Holmes, J. (2010): 'Verbal and mental processes in academic disciplines', in: Charles, M., Pecorari, D. and Hunston, S. (eds.) Academic writing: At the interface of corpus and discourse. London: Continuum.

Nieminen, J., Lindblom-Ylänne, S. and Lonka, K. (2004) 'The development of study orientations and study success in students of pharmacy'. Instructional Science, 32(5), pp. 387-417.

Shanahan, T. and Shanahan, C. (2012) 'What is disciplinary literacy and why does it matter?' Top Lang Disorders, 32(1), pp. 7-18.

Ulriksen, L., Murning, S. and Ebbensgaard, Aa. B. (2009) Når gymnasiet er en fremmed verden. Frederiksberg, Samfundslitteratur.

Wingate, U. (2015) Academic literacy and student diversity. The case for inclusive practice. Bristol: Multilingual Matters

\section{Author details}

Bente Kristiansen, Ph.D., is chief consultant at the Centre for Learning Development and Digital Media, Aarhus University. She has experience as a writing consultant for university students and as a pedagogical consultant. 